\title{
Biogenic oxidized organic functional groups in aerosol particles from a mountain forest site and their similarities to laboratory chamber products
}

\author{
R. E. Schwartz ${ }^{1}$, L. M. Russell ${ }^{1}$, S. J. Sjostedt ${ }^{2}$, A. Vlasenko ${ }^{2,3}$, J. G. Slowik ${ }^{2}$, J. P. D. Abbatt ${ }^{2}$, A. M. Macdonald ${ }^{3}$, \\ S. M. Li ${ }^{3}$, J. Liggio ${ }^{3}$, D. Toom-Sauntry ${ }^{3}$, and W. R. Leaitch ${ }^{3}$ \\ ${ }^{1}$ Scripps Institution of Oceanography, University of California, San Diego, La Jolla, California, USA \\ ${ }^{2}$ University of Toronto, Department of Chemistry, Toronto, ON, Canada \\ ${ }^{3}$ Environment Canada, Science and Technology Branch, Toronto, ON, Canada
}

Received: 10 February 2010 - Published in Atmos. Chem. Phys. Discuss.: 17 February 2010

Revised: 11 May 2010 - Accepted: 13 May 2010 - Published: 8 June 2010

\begin{abstract}
Submicron particles collected at Whistler, British Columbia, at $1020 \mathrm{~m}$ a.s.l. during May and June 2008 on Teflon filters were analyzed by Fourier transform infrared (FTIR) and X-ray fluorescence (XRF) techniques for organic functional groups (OFG) and elemental composition. Organic mass $(\mathrm{OM})$ concentrations ranged from less than 0.5 to $3.1 \mu \mathrm{g} \mathrm{m}^{-3}$, with a project mean and standard deviation of $1.3 \pm 1.0 \mu \mathrm{g} \mathrm{m}^{-3}$ and $0.21 \pm 0.16 \mu \mathrm{g} \mathrm{m}^{-3}$ for $\mathrm{OM}$ and sulfate, respectively. On average, organic hydroxyl, alkane, and carboxylic acid groups represented $34 \%, 33 \%$, and $23 \%$ of $\mathrm{OM}$, respectively. Ketone, amine and organosulfate groups constituted $6 \%, 5 \%$, and $<1 \%$ of the average organic aerosol composition, respectively. Measurements of volatile organic compounds (VOC), including isoprene and monoterpenes from biogenic VOC (BVOC) emissions and their oxidation products (methyl-vinylketone/methacrolein, MVK/MACR), were made using co-located proton transfer reaction mass spectrometry (PTR-MS). We present chemically-specific evidence of OFG associated with BVOC emissions. Positive matrix factorization (PMF) analysis attributed $65 \%$ of the campaign $\mathrm{OM}$ to biogenic sources, based on the correlations of one factor to monoterpenes and MVK/MACR. The remaining fraction was attributed to anthropogenic sources based on a correlation to sulfate. The functional group composition of the biogenic factor (consisting of 32\% alkane, $25 \%$ carboxylic acid, $21 \%$ organic hydroxyl, $16 \%$ ketone, and $6 \%$ amine groups) was similar to that of secondary or-
\end{abstract}

Correspondence to: L. M. Russell (lmrussell@ucsd.edu) ganic aerosol (SOA) reported from the oxidation of BVOCs in laboratory chamber studies, providing evidence that the magnitude and chemical composition of biogenic SOA simulated in the laboratory is similar to that found in actual atmospheric conditions. The biogenic factor OM is also correlated to dust elements, indicating that dust may act as a nonacidic SOA sink. This role is supported by the organic functional group composition and morphology of single particles, which were analyzed by scanning transmission X-ray microscopy near edge X-ray absorption fine structure (STXMNEXAFS).

\section{Introduction}

There is strong evidence that biogenic volatile organic compounds (BVOC) produce a large fraction of secondary organic aerosol (SOA). Globally, BVOC emissions may be 10 times greater than anthropogenic VOC emissions (Seinfeld and Pandis, 2006). Oxidation of BVOC yields a large biogenic contribution to SOA, with estimates ranging from 12 to $70 \mathrm{Tg} / \mathrm{yr}$ (Hallquist et al., 2009). There are many uncertainties in the estimates of SOA from BVOC, including the BVOC emissions, reaction yields, and oxidant levels (Simpson et al., 2007). Models predict that by 2100 the global SOA burden will double, as a result of increased biogenic SOA as well as human activities (Tsigaridis and Kanakidou, 2007). The influence of biogenic sources on global SOA is large and is also expected to increase with predicted changes in temperature, vegetation, and $\mathrm{CO}_{2}$ levels (Tsigaridis and Kanakidou, 2007). On average $60 \pm 10 \%$ of organic carbon

Published by Copernicus Publications on behalf of the European Geosciences Union. 
(OC) in Europe during the summer has been attributed to biogenic sources, and it is suggested that biogenic SOA far exceeds anthropogenic SOA in the summer even in urban centers such as Zürich (Szidat et al., 2006). The importance of BVOC oxidation to particle mass and number has been demonstrated by a number of studies influenced by a variety of different forested regions (Leaitch et al., 1999; Kulmala et al., 2001; Sellegri et. al., 2004; Rissanen et al., 2006; Russell et al., 2007). A peak biogenic SOA concentration of $15 \mu \mathrm{g} \mathrm{m}^{-3}$ (the largest to date) was reported at a rural site north of Toronto in Ontario, Canada (Slowik et al., 2010).

Laboratory chamber studies have identified several products of isoprene oxidation and of monoterpene oxidation; these products include carbonyls (both ketones and aldehydes), organic acids and hydroxyls, including triols and tetrols (Surratt et al., 2006; Kroll et al., 2006), and small amounts of organosulfates (Surratt et al., 2008). Significant progress has been made on understanding the proposed chemical mechanisms of the pathways for oxidation of BVOCs to form SOA (Surratt et al., 2010; Paulot et al., 2009). These controlled experiments have been run under a variety of conditions (varying oxidant concentrations, light, seed aerosol, relative humidity, and temperature), although almost always with only a single oxidant (Hallquist et al., 2009; Kanakidou et al., 2005). From measured stable products, likely pathways and intermediates have been proposed and varying yields have been calculated. In addition, the chemical composition of laboratory-produced biogenic SOA has been observed to change for some time after SOA formation has slowed (Sax et al., 2005).

There is very little evidence that these products identified in the laboratory are formed and persist in the real atmosphere. The pathways that are the most significant and relevant for atmospheric conditions remain unknown (Kanakidou et al., 2005; Hallquist et al., 2009). Laboratory chamber studies have provided quantitative information on specific pathways and yields, but they typically use controlled conditions with a single oxidant and no competing reactants an idealized situation rarely encountered in the atmosphere. In addition, as a result of the sensitivity of aerosol formation to the concentration of $\mathrm{NO}_{\mathrm{x}}$, the mass yields determined in the lab may not accurately represent those of ambient aerosol (Seinfeld and Pandis, 2006). Further ambient measurements of biogenic SOA are necessary to guide the myriad of results arising from chamber studies by providing constraints of real atmospheric conditions. However, the complexity of multiple atmospheric variables (such as transport times, mixing efficiencies, and multiple co-located sources) and their interplay in ambient conditions, as well as the multitude of different organic compounds, make ambient organic identification more challenging and often more limited than controlled laboratory studies (Goldstein and Galbally, 2007). Some methods such as gas chromatography-mass spectrometry can identify specific chemical biogenic SOA tracers but are limited to identifying only a fraction (at best $<25 \%$ ) of the atmospheric aerosol (Cahill et al., 2006). In situ atmospheric measurements have provided evidence that biogenic SOA has high ratios of oxygen to carbon. The large concentrations of biogenic SOA measured at Egbert, Canada, were constrained by a lower limit of the less-oxygenated organic aerosol (OOA-2, $\mathrm{O} / \mathrm{C} \sim 0.46)$ and an upper limit of the weighted sum of the more-oxygenated OOA-1 $(\mathrm{O} / \mathrm{C} \sim 0.81)$ and OOA-2 (Slowik et al., 2010). Slowik and colleagues approximate the $\mathrm{O} / \mathrm{C}$ ratio from the fraction of $m / z 44\left(\mathrm{CO}_{2}^{+}\right.$ ion) in the total organic mass spectrum, as presented by Aiken et al. (2008).

In this paper, we use an expanded suite of instrumentation and statistical techniques to present chemically-specific evidence for organic functional groups (OFG) associated with biogenic VOC emissions. The suite of gas and particle phase measurements at a mid-mountain site in the forests of Whistler, British Columbia, in May and June of 2008 are used to identify the sources and composition of the organic mass during this study, providing an opportunity to compare products observed in laboratory chamber studies to those formed under atmospheric conditions.

\section{Methods}

Atmospheric particles and gases were sampled by a suite of co-located instruments during a one-month campaign at a site in Whistler, BC, at $1020 \mathrm{~m}$ above sea level (a.s.l.). The valleys surrounding Whistler Mountain are lined by trees up to about 1850 ma.s.l. The forests are largely coniferous, dominated by firs and hemlock. The measurements at the Children's Learning Center (CLC) building on Whistler mountain included Fourier transform infrared (FTIR) spectroscopy, high-resolution time-of-flight aerosol mass spectrometry (HR-ToF-AMS), proton-transfer reaction mass spectrometry (PTR-MS), X-ray fluorescence (XRF), single particle soot photometer (SP2), Scanning Transmission X-Ray Microscopy with Near-Edge Absorption Fine Structure (STXM-NEXAFS), gas phase compounds (CO, $\mathrm{O}_{3}, \mathrm{NO}_{\mathrm{x}}$ ), and meteorological conditions from 16 May to 16 June 2008. In addition, Environment Canada (EC) maintains measurements of ozone, $\mathrm{CO}$, particle size distributions $(0.01-20 \mu \mathrm{m})$, ionic composition, light scattering, and light absorption at Whistler Peak at $2182 \mathrm{~m}$ a.s.l. (Leaitch et al., 2009).

FTIR provides organic functional group concentrations through chemical bond-based measurements (Russell et al., 2009a). Submicron particles were collected on $37 \mathrm{~mm}$ Teflon filters (Pall Inc.) downstream of a 1- $\mu \mathrm{m}$, sharp-cut cyclone (SCC 2.229 $\mathrm{PM}_{1}$, BGI Inc.). Overlapping duplicate samples of approximately 12 and $24 \mathrm{~h}$ duration were collected to provide redundant and higher loading samples. Filter changes generally occurred each morning (between 6 and 8 a.m. PST) and each evening (between 5 and 8 p.m. PST). Back filters were collected to monitor VOC adsorption by the filter 
material and handling artifacts, although the FTIR absorption of these filters was below detection limit (bdl) in all cases. The standard deviation of the collected blanks was added to the calculation of the sample precision. FTIR spectra, measured with a Tensor 27 spectrometer (Bruker, Billerica, MA), were fit with polynomial baselines and peaks associated with each OFG, including alkane, carboxylic acid, organic hydroxyl, amine, organosulfate, and non-acidic carbonyl (ester or ketone) group concentrations (Maria et al., 2002; Gilardoni et al., 2007; Russell et al., 2009a). Alkene, aromatic, phenol, and organonitrate groups were below detection limit for all samples collected during this project.

High resolution time-of-flight Aerosol Mass Spectrometry (HR-ToF-AMS, Aerodyne Research Inc., Billerica, MA) provides real-time measurements of non-refractory compounds including sulfate, nitrate, and organic mass through production of mass fragments by electron impact and detected by their mass to charge ratio $(\mathrm{m} / \mathrm{z}$ ) (Jayne et al., 2000; DeCarlo et al., 2006; Canagaratna et al., 2007). The AMS was operated in two modes: $\mathrm{V}$ and $\mathrm{W}$-mode. The high mass resolution of W-mode (3000-5000) allowed fragments of nominally the same $m / z$ to be quantified separately, thereby enabling a distinction between hydrocarbon $\left(\mathrm{C}_{\mathrm{x}} \mathrm{H}_{\mathrm{y}}\right)$ and oxygenated hydrocarbon (for example, $\mathrm{C}_{\mathrm{x}-1} \mathrm{H}_{\mathrm{y}-4} \mathrm{O}$ ). W-mode data analysis (i.e. quantification of individual $\mathrm{m} / \mathrm{z}$ with better than unit mass resolution) for this study was completed using a custom algorithm that incorporated a peak fitting procedure, typical AMS correction factors, and the correction for $\mathrm{O} / \mathrm{C}$ suggested by Aiken et al. (2008).

Mixing ratios of selected VOCs were measured using high-sensitivity PTR-MS acquired from IONICON Analytik (Innsbruck, Austria). PTR-MS measures VOC concentrations from mass fragments of VOCs with a proton affinity higher than that of water, including monoterpenes and isoprene which are taken to be representative of BVOC emissions (Guenther et al., 1995). In brief, ambient air is pumped into a drift tube where VOCs undergo proton-transfer reaction with $\mathrm{H}_{3} \mathrm{O}^{+}$ions produced by the ion source. Species with a proton affinity higher than water form stable ions that are selected with respect to $m / z$ and counted (de Gouw et al., 2009). The particular PTR-MS instrument and the sampling and calibration methods used here have been described previously (Vlasenko et al., 2009). One difference in operations was that a heated $\left(350^{\circ} \mathrm{C}\right)$ platinum glass wool catalyst (Shimadzu Scientific Instruments, Columbia, MD) was used for automatic background collection (for 14 min every $3 \mathrm{~h}$ ), as opposed to the activated charcoal used in the earlier study. As previously, a $500 \mathrm{ppb}$ Apel-Reimer standard was employed (with 22 calibration points), which contained isoprene, $\alpha$ pinene, and limonene. We assume that all monoterpenes are detected with the same average sensitivity as that measured for the sum of $\alpha$-pinene and limonene. Methanol and acetone were also measured. Similarly, we report mixing ratios for the sum of methacrolein (MACR) and methylvinylketone (MVK) that are detected at the same $m / z$ by the PTR-MS.
MVK was calibrated with the Apel-Reimer standard, and we assume MACR has the same sensitivity. Detection of other BVOCs such as pinonaldehyde was not possible because of low mixing ratios near the instrument's detection limit during the campaign.

A single particle soot photometer (SP2) (Droplet Measurement Technologies, Boulder, $\mathrm{CO}$ ) was used to measure black carbon (BC) in particles containing $\mathrm{BC}$ cores larger than about $70 \mathrm{~nm}$ diameter (Stephens et al., 2003; Schwarz et al., 2006; Slowik et al., 2007). Briefly, an air stream that contains BC passes through an air jet and intersects an intracavity and continuous Nd:YAG laser beam at $1064 \mathrm{~nm}$ wavelength. BC particles absorb the laser light and are heated to reach incandescence. The emitted incandescence light is detected using photomultiplier detectors. The peak incandescence signal is proportional to $\mathrm{BC}$ mass. The detector signals from individual particles are recorded at a high frequency, allowing the signals of each particle to be recorded and stored for further analysis. BC particle number concentrations are obtained by integrating the individual particles of different sizes from $70 \mathrm{~nm}$ and up.

$\mathrm{X}$-ray fluorescence analysis (XRF) of the same filters used for FTIR was carried out at Chester LabNet (Tigard, Oregon) and provides elemental composition of metals heavier than $\mathrm{Na}$ (Maria et al., 2003), including S, Si, Al, Fe, Ca, Ti, V, $\mathrm{K}, \mathrm{Cr}, \mathrm{Mn}, \mathrm{Ni}, \mathrm{Zn}$, and $\mathrm{Br}$. The remaining elements heavier than $\mathrm{Na}$ (including $\mathrm{Na}$ ) are also detected by this method but are omitted from this discussion because more than 34 of the 49 samples were below the detection limit.

Samples of atmospheric particles were collected for Scanning Transmission X-ray Microscopy Near Edge X-ray Absorption Fine Spectra (STXM-NEXAFS) by impaction on silicon nitride windows during 12 sampling periods, each of approximately 30 to $60 \mathrm{~min}$. STXM-NEXAFS provides single particle chemical composition, size, and morphology measurements (Takahama et al., 2007, 2010). Of these 12 samples, 89 particles from four windows were analyzed at the Advanced Light Source (ALS) at the Lawrence Berkeley Laboratories (LBL).

The submicron organic mass (OM) measured by FTIR and Q-AMS has been shown to agree within $20 \%$ in ambient studies with primarily non-refractory, smaller than $500 \mathrm{~nm}$, particles (Russell et al., 2009b). Figure 1 shows the comparison between the V mode of HR-ToF-AMS and FTIR OM measurements, for which the AMS OM concentrations were averaged for the filter sampling period and only samples in which the AMS measured OM for more than $85 \%$ of the sample duration are included. The average FTIR to V-mode HRTof-AMS ratio is 1.6 with correlation coefficient $(r)$ equal to 0.85 . Several of the samples with higher FTIR than AMS OM concentrations also contained a significant concentration of dust (as illustrated in Fig. 1), suggesting that OM on submicron dust is not adequately measured by the AMS. This result is consistent with similar findings in a high-dust region reported by Hawkins et al. (2010). Samples with Si 


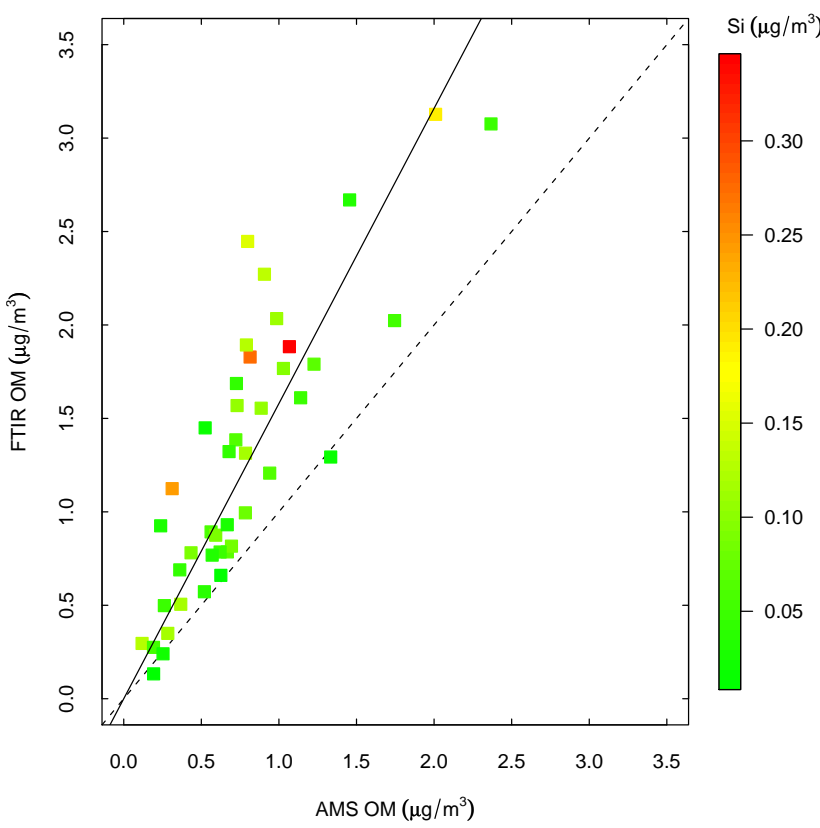

Fig. 1. Comparison of V mode HR- Tof-AMS and FTIR OM concentrations. Five-minute resolution HR-Tof-AMS data was averaged over each filter sampling period and only filter periods in which the AMS was collecting measurements for at least $85 \%$ of the sample period (with a $50 \%$ duty cycle in $\mathrm{V}$ mode) were used here. $1: 1$ line is shown by a dashed line. Linear regression produces a fit through the origin with slope of 1.6 and $r=0.85$.

concentrations below $0.05 \mu \mathrm{g} \mathrm{m}^{-3}$ have a slightly higher correlation of $r=0.89$ (V-mode) and lie closer to the 1:1 line. The average AMS sulfur (from sulfate) to XRF sulfur ratio is 0.31 with $r=0.91$. Comparisons to analysis of FTIR filters by ion chromatography (using the method of Toom-Sauntry and Barrie, 2002) show that most of the XRF S is present as sulfate. This implies that a portion of sulfate is not detected by the AMS and may be the result of the collection efficiency for sulfate and the transmission efficiency of the AMS. The different fractions of OM and sulfur collected by the AMS relative to offline impactors suggest that a majority of the OM is not present on the same particles as the sulfate.

\section{Results}

Whistler peak is influenced by long range transported particles from Asia in the early-spring, by biogenic aerosols in the late-spring and summer (Leaitch et al., 2009), and occasionally by biomass burning aerosols in summer. Vancouver is $100 \mathrm{~km}$ southwest of Whistler and is the closest large city. During the 2008 measurements at the mid-mountain site, the lack of nearby large pollution sources and specific meteorological conditions resulted in lower concentrations of atmospheric oxidants in the valley. The project means and standard deviations of $\mathrm{NO}_{\mathrm{x}}$ and $\mathrm{O}_{3}$ concentration, measured using a TECO $42 \mathrm{C}$ and TECO $49 \mathrm{C}$ (Thermo Electron Cor- poration, Waltham, MA), were $1.5 \pm 1$ and $28 \pm 11 \mathrm{ppbv}$, respectively (as listed in Table 1). The mean $\mathrm{NO}_{\mathrm{x}}$ is dominated by relatively short-lived increases due to local traffic and the morning breakup of the nocturnal inversion that formed below the CLC. The tall spikes in BC number concentration, shown in Fig. 2d, are attributed to diesel trucks from a nearby mountain road. The lower but broader increases in BC concentration during the late mornings are related to the nocturnal inversion breakup that carried pollutants accumulated over Whistler village through the site; the latter was rapidly diluted as the boundary layer grew. These factors account for less than a $10 \%$ increase in the $12 \mathrm{~h}$ average of more than $90 \%$ of the filter sampling periods. Overall these BC number concentrations are quite low (Jacobson, 2002), and there is no evidence to suggest the local truck emissions contributed more than $10 \%$ of OM.

The OFG composition is shown in Fig. 2a for the May and June 2008 measurement campaign. OM was composed of alkane, carboxylic acid, ketone, organic hydroxyl, and amine groups, with five samples containing detectable organosulfate groups. OM was variable throughout the project, ranging from less than 0.5 to $3.1 \mathrm{\mu g} \mathrm{m}^{-3}$, with the project mean and standard deviation at $1.3 \pm 1.0 \mu \mathrm{g} \mathrm{m}^{-3}$. On average, organic hydroxyl, alkane, and carboxylic acid groups represented $34 \%, 33 \%$, and $23 \%$ of OM, respectively. Ketone, amine, and organosulfate groups made up $6 \%, 5 \%$, and $<1 \%$ of the average organic aerosol composition, respectively.

The OFG concentrations show correlations with each other and dust, suggesting at least two distinct types of organic sources. Organic hydroxyl group fraction is mildly correlated to amine group fractions. In addition, organic hydroxyl and amine groups are strongly $(r=0.8)$ and mildly $(r=0.6)$ correlated with dust ( $\mathrm{Si})$, respectively, while alkane and carboxylic acid groups show no correlation $(r<0.25)$ to dust (Si). These differences suggest at least two distinct sources with varying OFG signatures contributing to $\mathrm{OM}$. There are weak correlations among several of the OFG and VOC. Weak correlations are consistent with both the formation of OFG from VOCs that are simultaneously removed as well as the multivariate nature of the dependence of $\mathrm{OM}$ on mixtures of sources, oxidants, and photochemical pathways.

A prominent feature of the time series of the summed OFG and BVOCs shown in Fig. 2a, b is the two large peaks in concentration during two different periods, "H1" (from 18:00 PST 16 May to 13:00 PST 19 May) and "H2" (from 18:00 PST 24 May to 08:00 PST 28 May). The time between and after these two periods also includes significantly increased concentrations of both monoterpenes (38 to $210 \mathrm{ppt})$ and $\mathrm{OM}\left(0.1\right.$ to $\left.2.3 \mu \mathrm{g} \mathrm{m}^{-3}\right)$. The temporal variations of isoprene and monoterpene concentrations are only weakly correlated. Secondary, longer-lived oxidation products of BVOCs, such as MVK/MACR, which in general had low mixing ratio values (a factor two higher than instrument noise), also had higher concentrations during $\mathrm{H} 1$ and $\mathrm{H} 2$ (listed in Table 1). 
Table 1. Time weighted Mean and Standard Deviation of Measured OM, OFGs, VOCs, Oxidants, PMF Factors and Elemental Concentrations for the Campaign and for Periods $\mathrm{H} 1$ and $\mathrm{H} 2$.

\begin{tabular}{|c|c|c|c|c|c|c|}
\hline & \multicolumn{2}{|r|}{ Campaign } & \multicolumn{2}{|r|}{$\mathrm{H} 1$} & \multicolumn{2}{|r|}{$\mathrm{H} 2$} \\
\hline & average & standard deviation & average & standard deviation & average & standard deviation \\
\hline \multicolumn{7}{|l|}{ OFG $(\%)$} \\
\hline Alkane Groups & 33 & 15 & 44 & 26 & 27 & 14 \\
\hline Organic Hydroxyl Groups & 34 & 13 & 14 & 5 & 41 & 10 \\
\hline Amine Groups & 5 & 3 & 6 & 5 & 5 & 2 \\
\hline Ketone Groups & 6 & 8 & 9 & 11 & 9 & 6 \\
\hline Carboxylic Acid Groups & 23 & 11 & 28 & 17 & 18 & 10 \\
\hline $\mathrm{OM}\left(\mu \mathrm{g} \mathrm{m}^{-3}\right)$ & 1.3 & 1 & 2.8 & 1.8 & 1.3 & 0.28 \\
\hline \multicolumn{7}{|l|}{ VOC (pptv) } \\
\hline Monoterpenes & 130 & 50 & 200 & 80 & 220 & 51 \\
\hline Isoprene & 35 & 12 & NA & NA & 49 & 17 \\
\hline MVK/MACR & 21 & 7.6 & 33 & 21 & 26 & 4.4 \\
\hline \multicolumn{7}{|l|}{$\operatorname{PMF}\left(\mu \mathrm{g} \mathrm{m}^{-3}\right)$} \\
\hline Summed Biogenic Factor & 0.78 & 0.83 & 2.2 & 1.5 & 1.1 & 0.44 \\
\hline Biogenic Part 1 & 0.36 & 0.31 & 0.24 & 0.18 & 0.77 & 0.43 \\
\hline Biogenic Part 2 & 0.23 & 0.52 & 1.3 & 0.89 & 0.28 & 0.26 \\
\hline Biogenic Part 3 & 0.42 & 0.57 & 1.2 & 1.3 & 0.33 & 0.26 \\
\hline Combustion Factor & 0.39 & 0.29 & 0.37 & 0.14 & 0.16 & 0.15 \\
\hline \multicolumn{7}{|l|}{ Oxidants (ppbv) } \\
\hline $\mathrm{NO}_{\mathrm{X}}$ & 1.5 & 1 & 0.75 & 0.55 & 0.73 & 0.54 \\
\hline $\mathrm{O}_{3}$ & 28 & 11 & 36 & 22 & 25 & 6.8 \\
\hline \multicolumn{7}{|l|}{$\mathrm{XRF}\left(\mu \mathrm{g} \mathrm{m}^{-3}\right)$} \\
\hline $\mathrm{S}$ & 0.11 & 0.14 & 0.23 & 0.17 & 0.08 & 0.039 \\
\hline $\mathrm{Si}$ & 0.038 & 0.054 & 0.047 & 0.041 & 0.081 & 0.077 \\
\hline $\mathrm{Al}$ & 0.026 & 0.038 & 0.025 & 0.021 & 0.058 & 0.053 \\
\hline $\mathrm{Fe}$ & 0.015 & 0.022 & 0.015 & 0.011 & 0.031 & 0.029 \\
\hline $\mathrm{K}$ & 0.007 & 0.008 & 0.014 & 0.009 & 0.011 & 0.008 \\
\hline $\mathrm{Ti}$ & 0.001 & 0.002 & 0.002 & 0.002 & 0.002 & 0.002 \\
\hline $\mathrm{Ca}$ & 0.007 & 0.013 & 0.015 & 0.013 & 0.016 & 0.015 \\
\hline
\end{tabular}

Note: OFG in which samples were bdl for greater than $75 \%$ of the samples are removed, PTR-MS measurements when the VOC were measured adl for more than $80 \%$ of the filter time are used. Bdl XRF were set to zero. The sum of the summed biogenic and combustion factor project OM $\left(1.2 \mathrm{ggm}^{-3}\right)$ was used to calculate the project biogenic fraction of $65 \%$. All high resolution measurements are averaged over FTIR filter time periods; all averages and standard deviations are time weighted by filter duration.

An interesting feature of the local activities near the mid-mountain site was a nearly continuous background of submicron dust components ranging from about 0.02 to $0.8 \mu \mathrm{g} \mathrm{m}^{-3}$. This submicron dust is probably associated with local sources because of its substantial concentration, its weak correlation with local wind speed, and the lack of evidence for free tropospheric influence of long-range transported Asian aerosols. The lack of a significant difference in day and night concentrations suggests that the submicron dust was either sufficiently long-lived that there was no temporal correlation to specific daytime activities on the mountain or that the majority of the dust was windblown rather than activity-related. The submicron dust elemental concen- trations (Fig. 3) were present in ratios similar to those found in Asia and North America (McKendry et al., 2001).The trace metal measurements from XRF included $\mathrm{S}, \mathrm{Si}$, and $\mathrm{Al}$, each with campaign average concentrations greater than $50 \mathrm{ng} \mathrm{m}^{-3}$. Fe, $\mathrm{Ca}, \mathrm{Ti}, \mathrm{V}, \mathrm{Cr}, \mathrm{Mn}, \mathrm{Ni}, \mathrm{Zn}$, and $\mathrm{Br}$ contributed from 0.4 to $34 \mathrm{ng} \mathrm{m}^{-3}$ over the study. The concentrations of crustal elements are shown in Fig. 2c.

We apply Positive Matrix Factorization (PMF, using PMF2 software purchased from P. Paatero, Helsinki University, based on Paatero and Tapper, 1994) to separate the fraction of the OFG that is most closely associated with the same sources as the BVOC emissions. This method has been used previously on FTIR spectra to identify and separate 


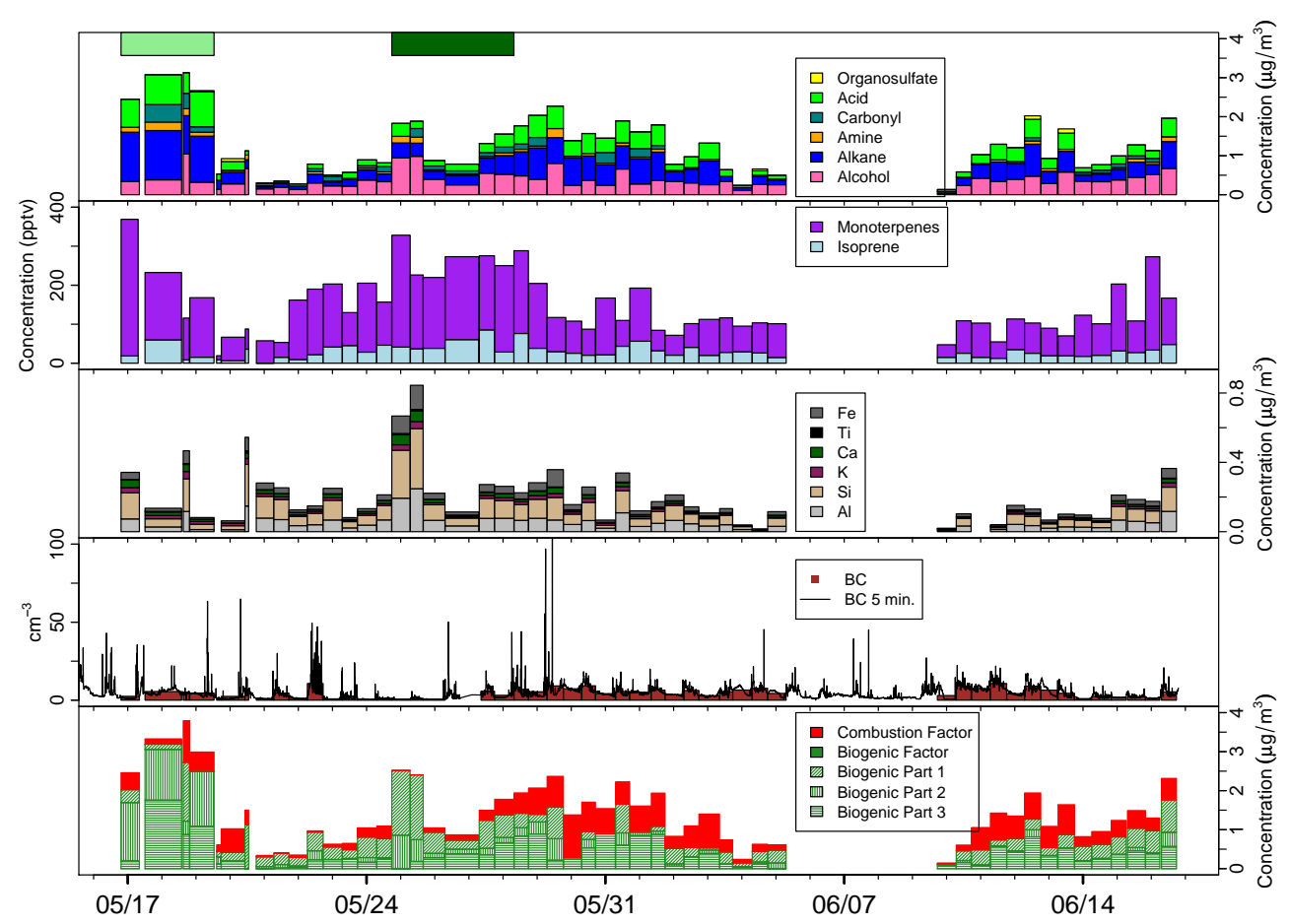

Fig. 2. Time series of measured and calculated submicron aerosol components with H1 (light green) and H2 (dark green) marked by top colored bars: (a) Time series of OM and OFG as stacked bars: organic hydroxyl (pink), alkane (blue), ketone (teal), amine (orange), acid (green), organosulfate (yellow) group concentrations; (b) shows the sum of isoprene (light blue) and monoterpenes (purple) concentration; (c) dust components $\mathrm{Al}$ (light grey), $\mathrm{Si}(\tan ), \mathrm{K}$ (maroon), Ca (dark green), Ti (black), Fe(dark grey); (d) Time series of 5 min average BC measurements (black) and $\sim 12 \mathrm{~h}$ averages (brown); (e) Time series of OM reconstructed from four-factor PMF.

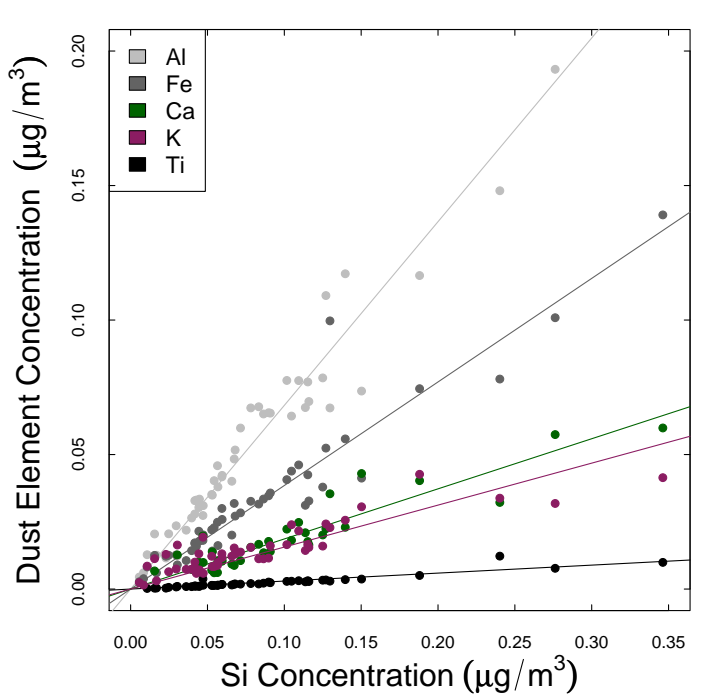

Fig. 3. Comparison of concentrations of several dust markers (Al, $\mathrm{Fe}, \mathrm{Ca}, \mathrm{K}, \mathrm{Ti})$ with $\mathrm{Si}$ for all above detection limit $12 \mathrm{~h}$ samples collected during the project. All 5 dust markers had strong correlations with $\mathrm{Si}$ and slopes of $0.68,0.38,0.19,0.16$, and 0.03 for $\mathrm{Al}, \mathrm{Fe}, \mathrm{Ca}$, $\mathrm{K}, \mathrm{Ti}$, respectively. combustion, wood burning, marine, and other sources (Russell et al., 2009a, 2010; Liu et al., 2009; Hawkins and Russell, 2010). PMF was applied on the 80 baselined FTIR spectra collected for 12 and $24 \mathrm{~h}$ samples, using an uncertainty matrix constructed as discussed in Russell et al. (2009a). Results for 2, 3, 4, 5, and 6 factor solutions with rotation parameter FPEAK of $-0.4,-0.2,0,0.2$, and 0.4 were explored. For more than four factors, two or more factors were correlated to each other, indicating that the measurements were insufficient to differentiate additional independent factors. For the four-factor solution the FPEAK range was expanded to -2 to 2 , and the $\mathrm{Q}$ values as a function of FPEAK were examined (Ulbrich et al., 2009). The effects of rotation close to zero were small, and those further from zero provide unrealistic spectra. FPEAK $=0.2$ was chosen for detailed investigation because of its low $\mathrm{Q}$ value and realistic spectra shape. To provide an estimate of the PMF spectra uncertainties, spectra for a range of three rotations are shown in Fig. 4.

The four-factor solution reproduced more than $90 \%$ of the absorbance. Three of the four factors obtained from this correlation were mildly or weakly correlated with monoterpene or isoprene concentrations and each other. Since these correlations mean that the factors were not independent, their sum is considered here as parts of a single factor (shown in Fig. 2e). The summed biogenic factor fraction is correlated 


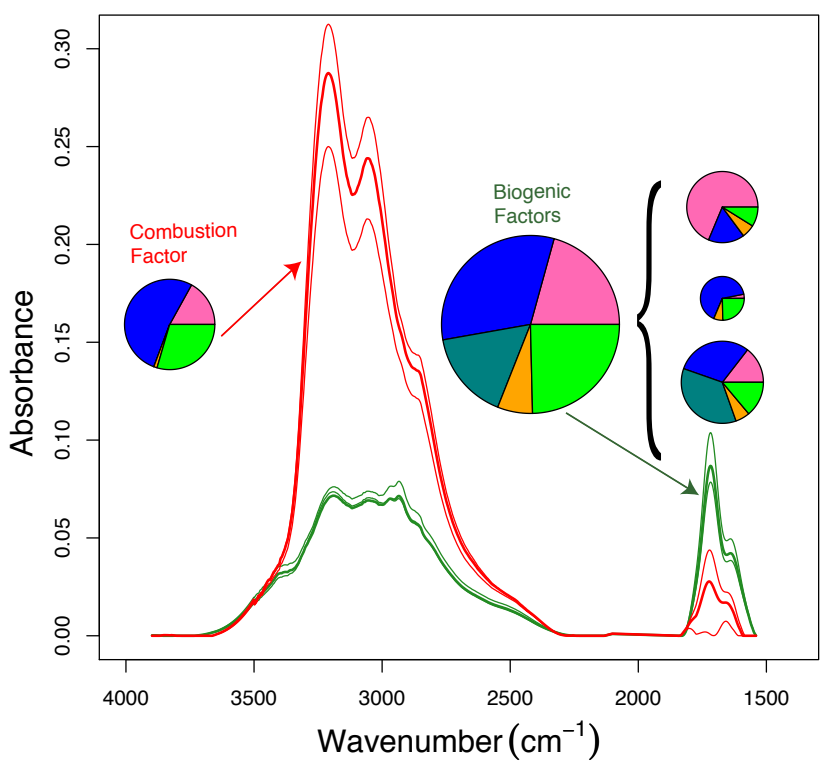

Fig. 4. FTIR spectra (for FPEAK of 0, 0.2 (bold), and 0.4) and OFG composition of summed biogenic and combustion PMF source factors. The pie charts show the average OFG composition for each factor, with the colors as given in Fig. 2 (organic hydroxyl (pink), alkane (blue), ketone (teal), amine (orange), acid (green)). The summed biogenic factor is made up of the three parts shown, where the composition pie for each part is scaled to its contribution to OM.

to monoterpenes and MVK/MACR with correlation coefficients of 0.69 and 0.63 , respectively, as shown in Fig. 5a, b. Because of the correlation to BVOC, this factor has been identified as a "biogenic" factor; it accounts for more than half of the OM $(65 \%)$ during the project and is more than $80 \%$ of $\mathrm{OM}$ during the $\mathrm{H} 1$ and $\mathrm{H} 2$ periods of higher monoterpene and isoprene concentrations. The fourth factor from PMF was weakly anti-correlated to monoterpenes $(r=-0.44)$, weakly correlated to BC, and mildly correlated to AMS sulfate and XRF S concentrations (Fig. 5d). The correlation to sulfur species suggests a fossil fuel combustion source for this OM and is referred to as the "combustion" factor. This factor may also include contributions from the port and urban areas of Vancouver as well as particles transported from Asian sources.

The average concentrations of the summed biogenic and combustion factors and their fractional composition of OFG are listed in Tables 1 and 2, respectively. The summed biogenic factor is composed of $32 \%(32-38 \%)$ alkane, $25 \%$ (22$25 \%$ ) carboxylic acid, $21 \%$ (19-21\%) organic hydroxyl, $16 \%$ (12-16\%) ketone, and 6\% (6-7\%) amine groups, where the range is for the PMF rotations shown in Fig. 4. The combustion factor is largely alkane $(52 \%, 50-57 \%)$ and carboxylic acid (30\%, 24-33\%) groups.

The correlation of the biogenic factor fraction with monoterpenes of $r=0.69$ is higher than the correlation of OM with monoterpenes $(r=0.33)$. This correlation of the
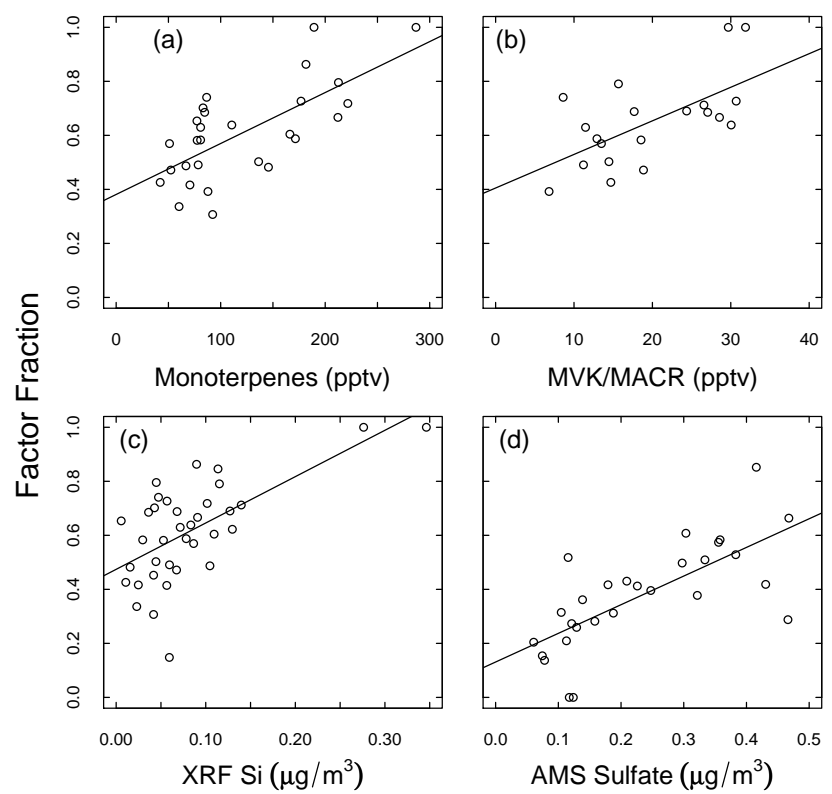

Fig. 5. Comparison of PMF fractions and important tracers. Biogenic factor fraction and (a) monoterpenes, (b) MVK/MACR (c) $\mathrm{Si}$, and Combustion factor fraction and (d) sulfate. Comparison includes $12 \mathrm{~h}$ samples with OM above detection, with four samples during 17-18 May omitted because the flow control was not operating during this time and PTR-MS measurements when the VOC were measured adl for more than $80 \%$ of the filter time. (OM concentrations were considered bdl for samples in which OFG mass contributions that were bdl accounted for more than $20 \%$ of OM.)

biogenic factor OM to monoterpenes is also higher than that of the OOA-2 factor identified from the more rapid time resolution AMS measurements at Egbert, ON (Slowik et al., 2010), because that factor was associated with both anthropogenic and biogenic sources during different time periods of the study. In addition, the Egbert site was $\geq 12 \mathrm{~h}$ downwind of the main BVOC emission sources rather than in the middle of the forest as at Whistler, resulting in closer correlation between BVOC precursors and SOA reaction products. It is also possible that the $12 \mathrm{~h}$ sample duration is sufficient to smear the time delay for the oxidation of monoterpenes and condensation of the oxidized products to form SOA, which we expect to be less than $10 \mathrm{~h}$ in similar atmospheric conditions (Russell et al., 2007). The correlation of BVOC concentrations to the biogenic OM factor identified by PMF is stronger than the correlations to the directly-measured OFG, supporting the interpretation of this factor as representing the fraction of the OM from a biogenic source. The biogenic factor is also correlated strongly $(r>0.75)$ or mildly $(0.5<r<0.75)$ with elements often used as tracers for dust ( $\mathrm{Al}, \mathrm{Si}, \mathrm{K}, \mathrm{Ti}$, and $\mathrm{Fe}$ ), in part because of two high concentration samples. The correlation between the biogenic factor fraction and $\mathrm{Si}(r=0.63)$ is shown in Fig. 5c. 
Table 2. OFG Fractional Composition of FTIR Factors and reported biogenic SOA from Hallquist et al. (2009) Tables 3, 4 and 5.

\begin{tabular}{|c|c|c|c|c|c|c|c|c|c|c|c|}
\hline & $\mathrm{O} / \mathrm{C}$ & $\begin{array}{l}\text { Alkane } \\
\text { Groups }\end{array}$ & $\begin{array}{l}\text { Ketone } \\
\text { Groups }\end{array}$ & $\begin{array}{l}\text { Aldehyde } \\
\text { Groups }\end{array}$ & $\begin{array}{l}\text { Organic } \\
\text { Hydroxyl } \\
\text { Groups }\end{array}$ & $\begin{array}{l}\text { Carboxlyic } \\
\text { Acid } \\
\text { Groups }\end{array}$ & $\begin{array}{l}\text { Organo- } \\
\text { sulfate } \\
\text { Groups }\end{array}$ & $\begin{array}{l}\text { Organo- } \\
\text { nitrate } \\
\text { Groups }\end{array}$ & $\begin{array}{l}\text { Alkene } \\
\text { Groups }\end{array}$ & $\begin{array}{l}\text { Amine } \\
\text { Groups }\end{array}$ & $\begin{array}{l}\text { FTIR } \\
\text { missing }\end{array}$ \\
\hline $\begin{array}{l}\text { PMF summed biogenic } \\
\text { factor }\end{array}$ & 0.6 & 32 & 16 & 0 & 21 & 25 & 0 & 0 & 0 & 6 & 0 \\
\hline Biogenic Part 1 & 1.1 & 16 & 0 & 0 & 69 & 9 & 0 & 0 & 0 & 6 & 0 \\
\hline Biogenic Part 2 & 0.2 & 66 & 0 & 0 & 3 & 25 & 0 & 0 & 0 & 7 & 0 \\
\hline Biogenic Part 3 & 0.6 & 30 & 36 & 0 & 15 & 14 & 0 & 0 & 0 & 6 & 0 \\
\hline PMF combustion factor & 0.4 & 52 & 0 & 0 & 17 & 30 & 0 & 0 & 0 & 1 & 0 \\
\hline Monoterpenes & 0.5 & 45 & 7 & 3 & 2 & 18 & 19 & 4 & 0 & 0 & 4 \\
\hline $\begin{array}{l}\text { 3-hydroxyglutaric } \\
\text { acid }^{\text {a, b, d }}\end{array}$ & 1 & 24 & 0 & 0 & 16 & 61 & 0 & 0 & 0 & 0 & 0 \\
\hline $\begin{array}{l}\alpha, \alpha- \\
\text { dimethyltricarballylic } \\
\text { acid }^{\text {a, b, c }}\end{array}$ & 0.8 & 31 & 0 & 0 & 0 & 66 & 0 & 0 & 0 & 0 & 3 \\
\hline 2,3-dihydroxypinane $\mathrm{d}^{\mathrm{d}}$ & 0.7 & 38 & 0 & 0 & 0 & 0 & 35 & 23 & 0 & 0 & 4 \\
\hline $\begin{array}{l}2,10- \\
\text { dihydroxypinane } \mathrm{d}, \mathrm{e}\end{array}$ & 0.5 & 45 & 0 & 0 & 9 & 0 & 41 & 0 & 0 & 0 & 5 \\
\hline 10-hydroxypinonic acid ${ }^{\mathrm{d}}$ & 0.7 & 35 & 10 & 0 & 0 & 16 & 36 & 0 & 0 & 0 & 3 \\
\hline pinonaldehyde ${ }^{\mathrm{f}}$ & 0.2 & 62 & 17 & 17 & 0 & 0 & 0 & 0 & 0 & 0 & 4 \\
\hline pinonic acid ${ }^{g}$ & 0.3 & 57 & 15 & 0 & 0 & 24 & 0 & 0 & 0 & 0 & 3 \\
\hline Isoprene & 1.4 & 22 & 2 & 3 & 35 & 10 & 27 & 3 & 3 & 0 & -5 \\
\hline 2-methyltetrol ${ }^{h}, \mathrm{i}, \mathrm{j}, \mathrm{n}$ & 0.8 & 14 & 0 & 0 & 92 & 0 & 0 & 0 & 0 & 0 & -6 \\
\hline $\begin{array}{l}\text { 2-methylglyceric } \\
\text { acid }^{\text {h, j, l, n }}\end{array}$ & 1 & 29 & 0 & 0 & 38 & 38 & 0 & 0 & 0 & 0 & -5 \\
\hline C5-alkene triols $1^{\mathrm{j}}$ & 0.6 & 36 & 0 & 0 & 58 & 0 & 0 & 0 & 11 & 0 & -5 \\
\hline $\begin{array}{l}\text { C5-alkene triols isomer } \\
2^{j}\end{array}$ & 0.6 & 30 & 0 & 0 & 58 & 0 & 0 & 0 & 22 & 0 & -10 \\
\hline glyoxal sulfate ${ }^{\mathrm{m}, \mathrm{n}}$ & 3 & 5 & 0 & 18 & 15 & 0 & 65 & 0 & 0 & 0 & -3 \\
\hline $\begin{array}{l}\text { methylglyoxal sulfates } \\
\text { isomer } 1^{\mathrm{m}}, \mathrm{n}\end{array}$ & 2 & 16 & 16 & 0 & 14 & 0 & 60 & 0 & 0 & 0 & -7 \\
\hline $\begin{array}{l}\text { methylglyoxal sulfates } \\
\text { isomer } 2^{\mathrm{m}, \mathrm{n}}\end{array}$ & 2 & 12 & 0 & 16 & 14 & 0 & 60 & 0 & 0 & 0 & -2 \\
\hline C5-alkane triol ${ }^{\mathrm{d}}$ & 1.6 & 26 & 0 & 0 & 9 & 0 & 42 & 28 & 0 & 0 & -5 \\
\hline $\begin{array}{l}2- \\
\text { hydroxymethylsuccinic } \\
\text { acid }^{\mathrm{g}}\end{array}$ & 1 & 24 & 0 & 0 & 16 & 61 & 0 & 0 & 0 & 0 & 0 \\
\hline $\begin{array}{l}\text { 2,3,4-trihydroxy-2- } \\
\text { methylbutyl hydrogen } \\
\text { sulfateg and 2- } \\
\text { methyltetrol sulfate } \\
\text { esters }^{\text {d }}\end{array}$ & 1.4 & 26 & 0 & 0 & 32 & 0 & 47 & 0 & 0 & 0 & -5 \\
\hline
\end{tabular}

${ }^{\mathrm{a}}$ Jaoui et al. (2005), ${ }^{\mathrm{b}}$ Claeys et al. (2007), ${ }^{\mathrm{c}}$ Szmigielski et al. (2007b), ${ }^{\mathrm{d}}$ Surratt et al. (2008), ${ }^{\mathrm{e}}$ Iinuma et al. (2007), ${ }^{\mathrm{f}}$ Williams et al. (2007), ${ }^{\mathrm{g}}$ Hallquist et al. (2009), ${ }^{\mathrm{h}}$ Edney et al. (2005), ${ }^{\mathrm{i}}$ Böge et al. (2006), ${ }^{\mathrm{j}}$ Surratt et al. (2006), ${ }^{\mathrm{k}}$ Claeys et al. (2004b), ${ }^{l}$ Szmigielski et al. (2007a), ${ }^{\mathrm{m}}$ Liggio et al. (2005a, b), ${ }^{\mathrm{n}}$ Surratt et al. (2007a).

The three individual parts of the summed biogenic factor show different strong, mild, and weak correlations with specific BVOC, OFG, and dust. For this reason, even though these three parts of the summed biogenic factor have sources that co-vary too much to be resolved independently, we consider the characteristics that differentiate each part. The first part of the biogenic factor, Part 1, consists mostly of organic hydroxyl groups $(69 \%, 68-72 \%)$ and is strongly correlated to the dust signal. To evaluate the role that the particle substrate may play in heterogeneous formation of SOA, we have also considered the correlation of the product of $\mathrm{Si}$ and monoter- pene concentrations with this part of the biogenic factor; this correlation is strong with $r=0.93$, with this correlation coefficient exceeding those of monoterpenes with the summed biogenic factor or with either of the other two parts. The second and smallest biogenic factor part, Part 2, is mildly correlated with monoterpenes $(r=0.64)$. This factor consists primarily of alkane $(66 \%, 56-66 \%)$ and acid $(25 \%, 24$ $32 \%$ ) groups. Part 3 of the summed biogenic factor is weakly $(r=0.30)$ correlated with isoprene when we include samples with above detection limit (adl) isoprene measurements for more than $50 \%$ of the filter time (and OM bdl samples 
are included). This factor has a significant fraction of ketone groups $(36 \%, 31-38 \%)$. In summary, the differences in the parts of the summed biogenic factor likely represent the products of different types of BVOC (namely isoprene and monoterpenes) as well as different SOA formation processes (such as condensation of organic hydroxyl group-containing products on dust instead of further oxidation to ketone or acid groups).

\section{Discussion}

Since OFG are characteristic of the organic compounds they make up, we expect the composition of the biogenic factor to resemble the composition of laboratory chamber SOA produced from oxidation of monoterpenes and isoprene. Table 2 summarizes the mass fractions of OFG in the reported SOA products from oxidation of monoterpenes, isoprene, and their mixtures. The observed ambient biogenic factor has $16 \%$ ketone groups, which is similar to the 10-17\% ketone groups from the reported smog chamber products 10-hydroxypinonic acid, pinonaldehyde, pinonic acid, and methylglyoxal sulfates (isomer 1) (Hallquist et al., 2009). The organic hydroxyl group composition $(21 \%)$ is similar to that of 3-hydroxyglutaric acid (16\%), 2-hydroxymethylsuccinic acid (16\%), and glyoxal sulfate (15\%), as shown in Table 2. The carboxylic acid fraction (25\%) is similar to that found for pinonic acid (24\%). The summed biogenic OM factor, like both C5-alkene triols isomers has an average $\mathrm{O} / \mathrm{C}$ of 0.6 . Several compounds shown in Table 2 contain small contributions of OFG not identified in the Whistler biogenic factor, and no single compound exactly matches the measured biogenic OFG composition. However, there are possible combinations, such as, a 2:1 ratio of pinonic acid to methyltetrol, that nearly reconstruct the overall biogenic factor OFG composition. Multiple combinations of more than 2 compounds also resemble the overall biogenic factor OFG composition.

Certainly there are many unidentified compounds that also contribute to the chamber SOA, and Table 2 shows only the similarity of the OFG in the identified compounds with those in the summed biogenic factor. To compare to the overall chamber SOA composition, we see that the $\mathrm{O} / \mathrm{C}$ ratio of the summed biogenic factor is slightly higher than the values for smog chamber SOA from both monoterpene and isoprene reactions (0.37 to 0.57) (Hallquist et al., 2009), but the chamber data are well within the range of Parts $2(0.2)$ and $3(0.6)$. The summed biogenic factor $\mathrm{O} / \mathrm{C}$ also exceeds the $\mathrm{O} / \mathrm{C}$ of the OOA-2 factor ( 0.46), which was during an identified biogenic period associated with biogenic SOA at Egbert (Slowik et al., 2010). The higher $\mathrm{O} / \mathrm{C}$ of the Whistler biogenic SOA could easily result from differences in atmospheric oxidant concentrations as well as in sampling methodology, since the high $\mathrm{O} / \mathrm{C}$ (1.1) in the organic hydroxyl group-containing Part 1 of the summed biogenic factor is likely formed on dust

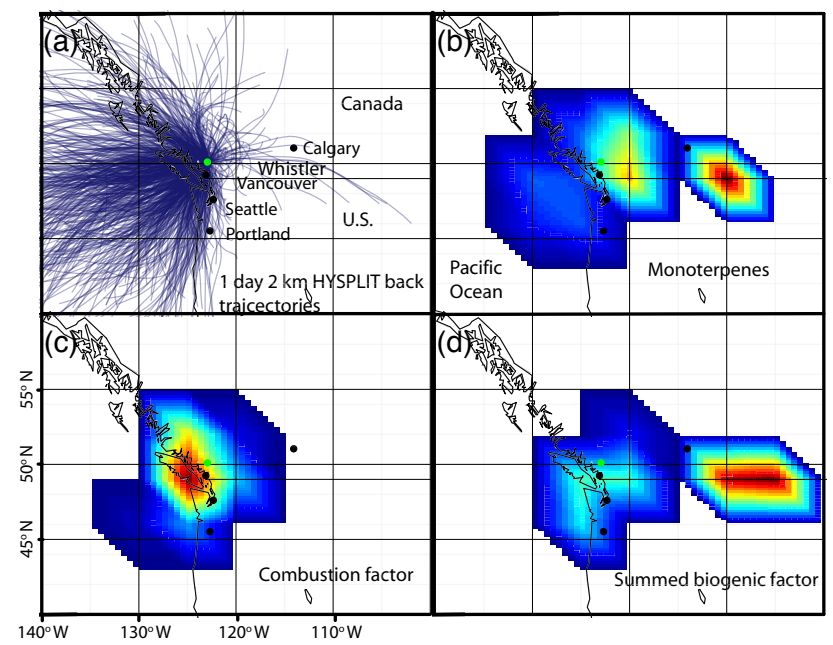

Fig. 6. Maps of British Columbia and surrounding regions showing (a) one day NOAA HYSPLIT back trajectories and potential sources contribution functions (PSCF) of (b) monoterpenes, (c) the combustion factor, and (d) the summed biogenic factor.

which is absent in chamber studies and either absent or not sampled at Egbert.

To identify the locations of the biogenic and combustion OM factors, we used Hybrid Single-Particle Lagrangian Integrated Trajectory (HYSPLIT, http://www.arl.noaa.gov/ HYSPLIT.php) back trajectories to evaluate the probability that the times during which the OM was largely from one factor (above the 75th percentile) coincided with a particular back trajectory region. We investigated 1 and 3 day back trajectories and chose the former, since the 3-day trajectories were disproportionately affected by a few unusual samples that did not reflect the majority of the study measurements. Figure 6 shows the one-day HYSPLIT back trajectories and maps of potential source contribution functions (PSCF) of monoterpenes, the summed biogenic factor, and the combustion factor (Pekney et al., 2006). The PSCF calculation indicates that the source regions of monoterpenes and the summed biogenic factor largely coincide with the forested regions to the east of Whistler. The small differences in the three parts of the biogenic factor may indicate differences in BVOC emissions from the vegetation in different regions. The source region identified for the combustion factor is southwest of Whistler, including the regions near the coastal cities of Vancouver, Seattle, and Portland, as well as the offshore shipping activities associated with their ports.

The summed biogenic factor is also correlated with the oxygenated VOCs methanol $(r=0.55)$ and acetone $(r=$ 0.69 ). This suggests that variations in these VOCs, especially acetone, are associated with products of BVOCs that may serve as precursors to the biogenic SOA or may simply be produced simultaneously (Vereecken and Peeters, 2000). This interpretation of methanol and acetone production from 

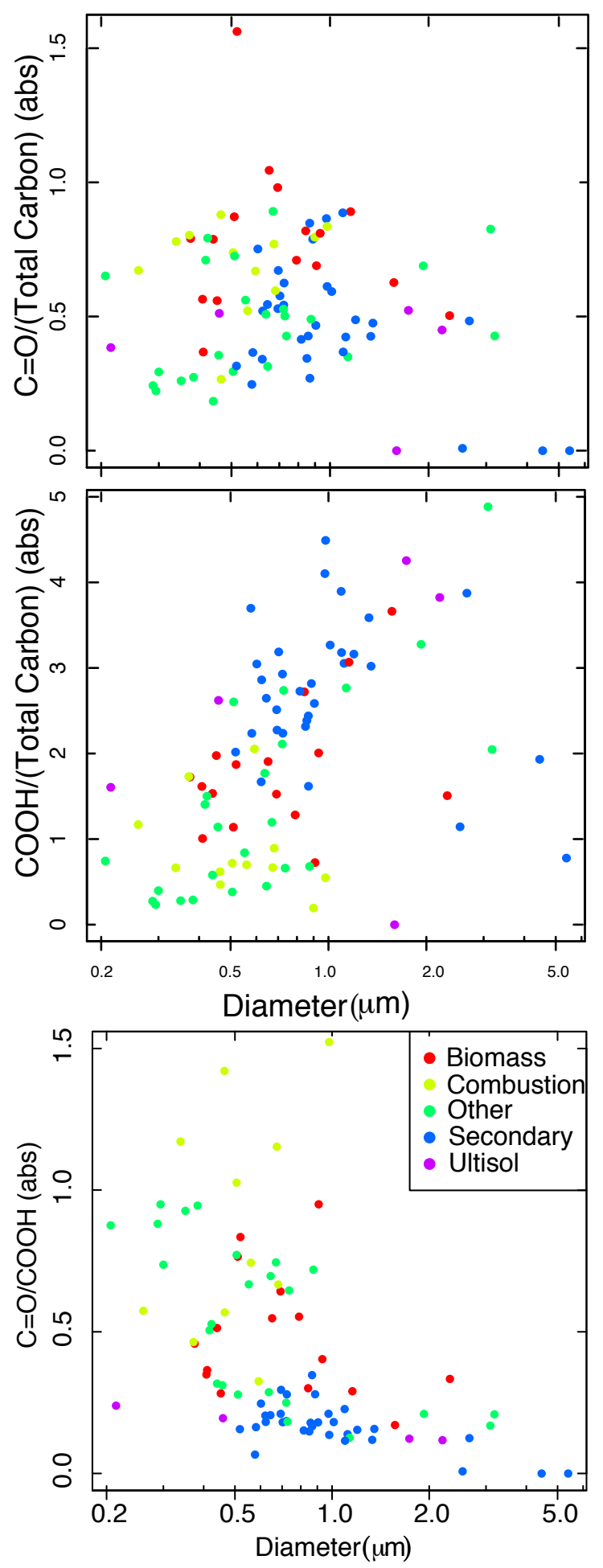

Fig. 7. Summary of ketone groups and carboxylic acid groups, for individual particles measured by STXM-NEXAFS, as a function of the apparent geometric diameter after impaction on the substrate. local biogenic sources is supported by observed strong diurnal variations of acetone, as such variations would tend to be reduced during transport from Vancouver or some other distant anthropogenic source.

The $0.02-0.8 \mu \mathrm{g} \mathrm{m}^{-3}$ concentrations of submicron dust components and the correlation of these components to the biogenic factor, suggests that dust acts as a surface for the condensation of products of BVOC oxidation. The correlation between the product of crustal elements and BVOCs with the biogenic factor $(r>0.9)$ provides some support for this speculation. Strong correlations between the biogenic factor and the product of OM and BVOCs $(r>0.8)$ are consistent with the two-product model of SOA formation, indicating that SOA condensation onto pre-existing organic particles may play a limiting role (Pankow, 1994; Odum et al., 1996).

The weakness of the correlations with BVOCs limits our ability to develop quantitative generalizations from these results. However, if there were a 4 to $12 \mathrm{~h}$ delay required to form SOA from BVOCs in the atmosphere, stronger correlations would not be expected. This time delay is more evident during the short duration $\mathrm{H} 1$ and $\mathrm{H} 2$ events, as is expected for Eulerian sampling with a variable temporal offset from the source region. However, the 12 to $24 \mathrm{~h}$ offset between the peaks in VOCs and the peaks in SOA suggests an SOA formation timescale of under a day. In addition to the delay associated with the chemical formation of biogenic SOA, there may also be an accumulation of BVOC contributions as the aerosol passes over multiple forested regions, which would also result in a lag between the peaks in BVOC and biogenic SOA concentrations.

The non-acidic carbonyl group contribution observed during this study is similar to the OM attributed to biogenic SOA in ICARTT (Bahadur et al., 2010) and to biomass burning emissions during measurements at the Scripps pier (Hawkins and Russell, 2010). This observation of ketone groups associated with both the emissions of plants and the burning of plants is enabled by the suitability of FTIR for detecting ketone groups (Calogirou et al., 1999). The high organic hydroxyl group factor, and its strong association with dust, suggests a different SOA formation pathway that has only been identified in Whistler.

In order to better understand the role of the ketone and carboxylic acid groups in biogenic SOA, we have classified the 89 particles analyzed by NEXAFS-STXM into the 14 categories presented by Takahama et al. (2007). The two most common particle types for the 89 particles were "secondary" (type "a") and "other" (types "k", "l", and "n") containing 32 and 24 particles, respectively. The remaining particles were classified as biomass burning (types " $\mathrm{i}$ " and " $\mathrm{j}$ ”), combustion (types "b" - "e", "g", "h", and "m"), and ultisol-soil (type "f"). As shown in Fig. 7, the "other" particles have a higher ratio of ketone to carboxylic acid groups than the "secondary" particles. The "secondary" particles also tend to be larger in size. This distinction is consistent with the results 
from the PMF factors of the FTIR submicron filter-based measurements that most of the ketone groups are formed from a different source or process than the carboxylic acid groups, as shown in Fig. 4 by the biogenic and combustion factor OFG compositions. The size differences suggest that at least some of the higher carboxylic acid group fractions may be from cloud processing, since reactions in cloud droplets may result in high SOA yields and more particle growth (Altieri et al., 2008). Conversely, the ketone group ratios are higher on many of the submicron particles since the higher contribution at smaller diameters suggests they are more likely to have formed from gas phase reactions (Maria et al., 2004).

\section{Conclusions}

The ambient OM concentrations at Whistler ranged from less than 0.5 to $3.1 \mu \mathrm{g} \mathrm{m}^{-3}$, with two distinct periods that corresponded to high concentrations of gas phase monoterpenes and isoprene as well as OM. About $65 \%$ of OM during the month-long study and over $80 \%$ during the periods of high monoterpene and isoprene concentrations was associated with secondary biogenic OM. The OFG composition of this biogenic OM differs from those compositions associated in other field campaigns with fossil fuel combustion and marine emissions (Russell et al., 2009a, 2010; Liu et al., 2009).

These findings provide one of the most unambiguous data sets for characterizing the functional group composition of ambient biogenic SOA. The presence of alkane, carboxylic acid, ketone, and organic hydroxyl groups in biogenic SOA is qualitatively consistent with both smog chamber results and with other biogenic OFG measurements (Hallquist et al., 2009; Bahadur et al., 2010). In fact, the similarity of the quantitative contributions of OFGs in the summed biogenic factor to those in the products identified from laboratory chamber SOA provides preliminary evidence for the atmospheric importance of the production and persistence of ketone and organic hydroxyl groups rather than aldehyde or organosulfate groups. While the differences between atmospheric SOA and laboratory chamber SOA are expected given the lower levels of both oxidants and BVOCs at Whistler during the study period, the similarities provide an indication of which products are more common and more stable in the atmosphere. The absence of aldehyde groups in the ambient SOA could also result from the sampling methods, or it may indicate that aldehydes are too volatile or reactive to persist in atmospheric particles (Pan et al., 2009; Jang and Kamens, 2001).

Acknowledgements. Sample collection and analysis were supported by NSF grant ATM-0511772 and the J. S. McDonnell Foundation. RES also acknowledges the support of a UC Regents Graduate fellowship. PTR-MS measurements were supported by the Cloud Aerosol Feedbacks and Climate project funded by the Canadian Foundation for Climate and Atmospheric Sciences.
Infrastructure support came in part from the Canada Foundation for Innovation and the Ontario Innovation Trust. We thank Whistler-Blackcomb for site access and help with logistics, as well as Juniper Buller for assistance in collecting filters at Whistler during this campaign.

Edited by: M. C. Facchini

\section{References}

Aiken, A. C., DeCarlo, P. F., Kroll, J. H., Worsnop, D. R., Huffman, J. A., Docherty, K. S., Ulbrich, I. M., Mohr, C., Kimmel, J. R., Sueper, D., Sun, Y., Zhang, Q., Trimborn, A., Northway, M., Ziemann, P. J., Canagaratna, M. R., Onasch, T. B., Alfarra, M. R., Prevot, A. S. H., Dommen, J., Duplissy, J., Metzger, A., Baltensperger, U., and Jimenez, J. L.: O/C and OM/OC Ratios of Primary, Secondary, and Ambient Organic Aerosols with HighResolution Time-of-Flight Aerosol Mass Spectrometry, Environ. Sci. Technol., 42, 4478-4485, doi:10.1021/es703009q, 2008.

Altieri, K. E., Seitzinger, S. P., Carlton, A. G., Turpin, B. J., Klein, G. C., and Marshall, A. G.: Oligomers formed through in-cloud methylglyoxal reactions: Chemical composition, properties, and mechanisms investigated by ultra-high resolution FT-ICR mass spectrometry, Atmos. Environ., 42, 1476-1490, 2008.

Bahadur, R., Uplinger, T., Russell, L. M., Sive, B. C., Cliff, S. S., Millet, D. B., Goldstein, A., and Bates, T. S.: Phenols in Northeastern US Submicron Aerosol Particles from Seawater Sources, Environ. Sci. Technol., accepted (available for review at http://aerosols.ucsd.edu/publications.html), 2010.

Böge, O., Miao, Y., Plewka, A., and Herrmann, H.: Formation of secondary organic particle phase compounds from isoprene gasphase oxidation products: An aerosol chamber and field study, Atmos. Environ., 40, 2501-2509, 2006.

Cahill, T. M., Seaman, V. Y., Charles, M. J., Holzinger, R., and Goldstein, A. H.: Secondary organic aerosols formed from oxidation of biogenic volatile organic compounds in the Sierra Nevada Mountains of California, J. Geophys. Res., 111, D16312, doi:10.1029/2006JD007178, 2006.

Calogirou, A., Larsen B. R., Kotzias, D.: Gas-phase terpene oxidation products: a review, Atmos. Environ., 33, 1423-1439, 1999.

Canagaratna, M. R., Jayne, J. T., Jimenez, J. L., Allan, J. D., Alfarra, M. R., Zhang, Q., Onasch, T. B., Drewnick, F., Coe, H., Middlebrook, A., Delia, A., Williams, L. R., Trimborn, A. M., Northway, M. J., DeCarlo, P. F., Kolb, C. E., Davidovits, P., and Worsnop, D. R.: Chemical and microphysical characterization of ambient aerosol with the Aerodyne aerosol mass spectrometer, Mass. Spectrom. Rev., 26, 185-222, 2007.

Claeys, M., Wang, W., Ion, A. C., Kourtchev, I., Gelencser, A., and Maenhaut, W.: Formation of secondary organic aerosols from isoprene and its gas-phase oxidation products through reaction with hydrogen peroxide, Atmos. Environ., 38, 4093-4098, 2004.

de Gouw J. A., Warneke C., Montzka S. A., Brioude, J., Holloway, J. S., Parrish, D. D., Fehsendfeld, F. C.: How much biogenic SOA is present in the Northeastern USA, Geochim Cosmochim AC., 73, A273-A273, 2009.

DeCarlo, P. F., Kimmel, J. R., Trimborn, A., Jayne, J. T., Aiken, A. C., Gonin, M., Fuhrer, K., Horvath, T., Docherty, K. S., Worsnop, D. R., and Jimenez, J. L.: A field-deployable high-resolution 
time-of-light aerosol mass spectrometer, Anal. Chem., 78, 82818289, 2006.

Edney, E. O., Kleindienst, T. E., Jaoui, M., Lewandowski, M., Offenberg, J. H., Wang, W., and Claeys, M.: Formation of 2methyltetrols and 2-methylglyceric acid in secondary organic aerosol from laboratory irradiated isoprene/ $\mathrm{NO}_{\mathrm{x}} / \mathrm{SO}_{2} /$ air mixtures and their detection in ambient $\mathrm{PM}_{2.5}$ samples collected in the eastern United States, Atmos. Environ., 39, 5281-5289, 2005.

Gilardoni, S., Russell, L. M., Sorooshian, A., Flagan, R. C., Seinfeld, J. H., Bates, T. S., Quinn, P. K., Allan, J. D., Williams, B., Goldstein, A. H., Onasch, T. B., and Worsnop, D. R.: Regional variation of organic functional groups in aerosol particles on four US east coast platforms during the International Consortium for Atmospheric Research on Transport and Transformation 2004 campaign, J. Geophys. Res.-Atmos., 112, D10S27, doi:10.1029/2006JD007737, 2007.

Goldstein, A. H. and Galbally, I. E.: Known and Unexplored Organic Constituents in the Earth's Atmosphere, Environ. Sci. Technol., 41, 1514-1521, 2007.

Guenther, A., Hewitt, C., Erickson, D., Fall, R., Geron, C., Graedel, T., Harley, P., Klinger, L., Lerdau, M., McKay, W., Pierce, T., Scholes, R., Steinbrecher, R., Tallamraju, R., Taylor, J., and Zimmerman, P.: A global model of natural volatile organic compound emissions, J. Geophys. Res., 100, 8873-8892, 1995.

Hallquist, M., Wenger, J. C., Baltensperger, U., Rudich, Y., Simpson, D., Claeys, M., Dommen, J., Donahue, N. M., George, C., Goldstein, A. H., Hamilton, J. F., Herrmann, H., Hoffmann, T., Iinuma, Y., Jang, M., Jenkin, M. E., Jimenez, J. L., Kiendler-Scharr, A., Maenhaut, W., McFiggans, G., Mentel, Th. F., Monod, A., Prévôt, A. S. H., Seinfeld, J. H., Surratt, J. D., Szmigielski, R., and Wildt, J.: The formation, properties and impact of secondary organic aerosol: current and emerging issues, Atmos. Chem. Phys., 9, 5155-5236, doi:10.5194/acp-95155-2009, 2009.

Hawkins, L. N., Russell, L. M., Covert, D. S., Quinn, P. K., and Bates T. S.: Carboxylic Acids, Sulfates, and Organosulfates in Processed Continental Organic Aerosol over the Southeast Pacific Ocean during VOCALS-REx 2008, Geophys. Res. Lett., in review, (available for review at http://aerosols.ucsd.edu/ publications.html), 2010.

Hawkins, L. N. and L. M. Russell, Oxidation of ketone groups in transported biomass burning aerosol from the 2008 Northern California Lightning Series fres, in review, available for review at http://aerosols.ucsd.edu/publications.html), 2010.

Iinuma, Y., Müller, C., Berndt, T., Böge, O., Claeys, M., and Herrmann, H.: Evidence for the existence of organosulfates from beta-pinene ozonolysis in ambient secondary organic aerosol, Environ. Sci. Technol., 41, 6678-6683, 2007.

Jacobson, M. Z.: Control of fossil-fuel particulate black carbon and organic matter, possibly the most effective method of slowing global warming, J. Geophys. Res., 107(D19), 4410, doi:10.1029/2001JD001376, 2002.

Jang, M. and Kamens, R. M.: Characterization of Secondary Aerosol from the Photooxidation of Toluene in the Presence of $\mathrm{NO}_{\mathrm{x}}$ and 1-Propene, Environ. Sci. Technol., 35, 3626-3639, 2001.

Jaoui, M., Kleindienst, T. E., Lewandowski, M., Offenberg, J. H., and Edney, E. O.: Identification and quantification of aerosol polar oxygenated compounds bearing carboxylic or hydroxyl groups: 2. Organic tracer compounds from monoterpenes, Environ. Sci. Technol., 39, 5661-5673, 2005.

Jayne, J. T., Leard, D. C., Zhang, X., Davidovits, P., Smith, K. A., Kolb, C. E., and Worsnop, D. R.: Development of an aerosol mass spectrometer for size and composition analysis of submicron particles, Aerosol Sci. Tech., 33, 49-70, 2000.

Kanakidou, M., Seinfeld, J. H., Pandis, S. N., Barnes, I., Dentener, F. J., Facchini, M. C., Van Dingenen, R., Ervens, B., Nenes, A., Nielsen, C. J., Swietlicki, E., Putaud, J. P., Balkanski, Y., Fuzzi, S., Horth, J., Moortgat, G. K., Winterhalter, R., Myhre, C. E. L., Tsigaridis, K., Vignati, E., Stephanou, E. G., and Wilson, J.: Organic aerosol and global climate modelling: a review, Atmos. Chem. Phys., 5, 1053-1123, doi:10.5194/acp-5-1053-2005, 2005.

Kroll, J. H., Ng, N. L., Mur phy, S. M., Flagan, R. C., and Seinfeld, J. H.: Secondary aerosol formation from isoprene photooxidaation, Environ. Sci. Technol., 40, 1869-1877, 2006.

Kulmala, M., Hämeri, K., Aalto, P. P., Mäkelä, J. M., Pirjola, L., Nilsson, E. D., Buzorius, G., Rannik, U, Dal Maso, M., Seidl, W., Hoffmann, T., Janson, R., Hansson, H. -C., Viisanen, Y., Laakonen, A., and O'Dowd, C. D.: Overview of the international project on Biogenic aerosol formation in the boreal forest (BIOFOR), Tellus 53B, 324-343, 2001.

Leaitch, W. R., Bottenheim, J. W., Biesenthal, T. A., Li, S. M., Liu, P. S. K., Asalian, K., Dryfhout-Clark, H., Hopper, F., and Brechtel, F.: A case study of gas-to-particle conversion in an eastern Canadian forest, J. Geophys. Res., 104, 8095-8111, 1999.

Leaitch, W. R., Macdonald, A. M., Anlauf, K. G., Liu, P. S. K., Toom-Sauntry, D., Li, S.-M., Liggio, J., Hayden, K., Wasey, M. A., Russell, L. M., Takahama, S., Liu, S., van Donkelaar, A., Duck, T., Martin, R. V., Zhang, Q., Sun, Y., McKendry, I., Shantz, N. C., and Cubison, M.: Evidence for Asian dust effects from aerosol plume measurements during INTEXB 2006 near Whistler, BC, Atmos. Chem. Phys., 9, 3523-3546, doi:10.5194/acp-9-3523-2009, 2009.

Liggio, J., McLaren, R., and Li, S. -M.: Heterogeneous reactions of glyoxal in particulate matter: Identification of acetals and sulfate esters, Environ. Sci. Technol., 39, 1532-1541, 2005a.

Liggio, J., McLaren, R., and Li, S. -M.: Reactive uptake of glyoxal on particulate matter, J. Geophys. Res., 110, D10304, doi:10.1029/2004JD005113, 2005b.

Liu, S., Takahama, S., Russell, L. M., Gilardoni, S., and Baumgardner, D.: Oxygenated organic functional groups and their sources in single and submicron organic particles in MILAGRO 2006 campaign, Atmos. Chem. Phys., 9, 6849-6863, doi:10.5194/acp9-6849-2009, 2009.

Maria, S. F., Russell, L. M., Turpin, B. J., and Porcja, R. J.: FTIR measurements of functional groups and organic mass in aerosol samples over the Caribbean, Atmos. Environ., 36(33), 51855196, 2002.

Maria, S. F., Russell, L. M., Gilles, M. K., and Myneni S. C. B.: Organic aerosol growth mechanisms and their climate-forcing implications, Science 306, 1921-1925, doi:10.1126/science.1103491, 2004.

McKendry, I. G., Hacker, J. P., Stull, R., Sakiyama, S., Mignacca, D., and Reid, K.: Long range transport of Asian dust to the Lower Fraser Valley, British Columbia, Canada, J. Geophys. Res., 106(D16), 18361-18370, 2001. 
Odum, J. R., Hoffmann, T., Bowman, F., Collins, D., Flagan, R. C., and Seinfeld, J. H.: Gas/particle partitioning and secondary organic aerosol yields, Environ. Sci. Technol., 30, 2580-2585, 1996.

Paatero, P. and Tapper, U.: Positive Matrix Factorization: A nonnegative factor model with optimal utilization of error estimates of data values, Environmetrics, 5, 111-126, 1994.

Pan, X., Underwood, J. S., Xing, J.-H., Mang, S. A., and Nizkorodov, S. A.: Photodegradation of secondary organic aerosol generated from limonene oxidation by ozone studied with chemical ionization mass spectrometry, Atmos. Chem. Phys., 9, 38513865, doi:10.5194/acp-9-3851-2009, 2009.

Pankow, J. F.: An Absorption Model of Gas/Particle Partitioning of Organic Compounds in the Atmosphere, Atm. Env. 28, 185-188, 1994.

Paulot, F. and Crounse, J. D. and Kjaergaard, H. G. and Kurten, A. and St Clair, J. M. and Seinfeld, J. H. and Wennberg, P. O.: Unexpected epoxide formation in the gas-phase photooxidation of isoprene, Science, 325, 730-733, doi:10.1126/science. 1172910, 2009.

Pekney, N. J., Davidson, C. I., Zhou, L. M., and Hopke, P. K.: Application of PSCF and CPF to PMF-modeled sources of $\mathrm{PM}_{2.5}$ in Pittsburgh, Aerosol Sci. Technol., 40, 952-961, 2006.

Rissanen, T., Hyötyläinen, T., Kallio, M., Kronholm, J., Kulmala, M., Riekkola, M.-L.: Characterization of organic compounds in aerosol particles from a coniferous forest by GC-MS, Chemosphere, 64, 1185-1195, 2006.

Russell, L. M., Mensah, A. A., Fischer, E. V., Sive B. C., Varner, R. K., Keene, W. C., Stutz, J., and Pszenny, A. A. P.: Nanoparticle Growth Following Photochemical a- and b-pinene Oxidation at Appledore Island During International Consortium for Research on Transport and Transformation/Chemistry of Halogens at the Isles of Shoals 2004, J. Geophys. Res. Atms. 112, D10S21, dio:10.29/2006JD007736, 2007.

Russell, L. M., Bahadur, R., Hawkins, L. N., Allan, J., Baumgardner, D., Quinn, P. K., and Bates, T. S.: Organic Aerosol Characterization by Complementary Measurements of Chemical Bonds and Molecular Fragments, Atmos. Environ., 43, 61006105, doi:10.1016/j.atmosenv.2009.09.036, 2009a.

Russell, L. M., Takahama, S., Liu, S., Hawkins, L. N., Covert, D. S., Quinn, P. K., and Bates, T. S.: Oxygenated Fraction and Mass of Organic Aerosol from Direct Emission and Atmospheric Processing Collected on the R/V Ronald Brown during TEXAQS/GoMACCS 2006, Journal of Geophysical Research-Atmospheres, 114, D00F05, doi:10.1029/2008JD011275, 2009b.

Russell, L. M., Hawkins, L. N., Frossard, A. A., Quinn, P. K., and Bates T. S.: Carbohydrate-like composition of submicron atmospheric particles and their production from ocean bubble bursting, Proc. Nat. Acad. Sci., 107(15), 6652-6657, 2010.

Sax, M., Zenobi, R., Baltensperger, U., and Kalberer, M.: Time resolved infrared spectroscopic analysis of aerosol formed by photo-oxidation of 1,3,5-trimethylbenzene and $\alpha$-pinene, Aerosol Sci. Technol., 39, 822-830, 2005.

Schwarz, J. P., Gao, R. S., Fahey, D. W., Thomson, D. S., Watts, L. A., Wilson, J. C., Reeves, J. M., Baumgardner, D. G., Kok, G. L., Chung, S., Schulz, M., Hendricks, J., Lauer, A., Kärcher, B., Slowik, J. G., Rosenlof, K. H., Thompson, T. L., Langford, A. O., Lowenstein, M., and Aikin, K. C.: Single-Particle Measurements of Midlatitude Black Carbon and Light-Scattering Aerosols from the Boundary Layer to the Lower Stratosphere. J. Geophys. Res., 111, D16207, doi:10.1029/2006JD007076, 2006.

Seinfeld, J. H. and Pandis, S. N., Atmospheric Chemistry and Physics Second Edition, Wiley-Interscience, New York, NY, USA, 43-46, 2006.

Sellegri, K., Hanke, M., Umann, B., Arnold, F., and Kulmala, M.: Measurements of organic gases during aerosol formation events in the boreal forest atmosphere during QUEST, Atmos. Chem. Phys., 5, 373-384, doi:10.5194/acp-5-373-2005, 2005.

Simpson, D., Yttri, K., Klimont, Z., Kupiainen, K., Caseiro, A., Gelencsèr, A., Pio, C., and Legrand, M.: Modeling carbonaceous aerosol over Europe. Analysis of the CARBOSOL and EMEP EC/OC campaigns, J. Geophys. Res., 112, D23S14, doi:10.1029/2006JD008158, 2007.

Slowik, J. G., Cross, E. S., Han, J. -H., Davidovits, P., Onasch, T. B., Jayne, J. T., Williams, L. R., Canagaratna, M. R., Worsnop, D. R., Chakrabarty, R. K., Moosmüller, H., Arnott, W. P., Schwarz, J. P., Gao, R. -S., Fahey, D. W., Kok, G. L., and Petzold, A.: An Inter-Comparison of Instruments Measuring Black Carbon Content of Soot Particles, Aerosol Sci. Technol., 41, 295-314, doi:10.1080/02786820701197078, 2007.

Slowik, J. G., Stroud, C., Bottenheim, J. W., Brickell, P. C., Chang, R. Y.-W., Liggio, J., Makar, P. A., Martin, R. V., Moran, M. D., Shantz, N. C., Sjostedt, S. J., van Donkelaar, A., Vlasenko, A., Wiebe, H. A., Xia, A. G., Zhang, J., Leaitch, W. R., and Abbatt, J. P. D.: Characterization of a large biogenic secondary organic aerosol event from eastern Canadian forests, Atmos. Chem. Phys., 10, 2825-2845, doi:10.5194/acp-10-2825-2010, 2010.

Stephens, M., Turner, N., and Sandberg, J.: Particle identification by laser-induced incandescence in a solid-state laser cavity, Appl. Optics, 42, 3726-3736 2003.

Surratt, J. D., Murphy, S. M., Kroll, J. H., Ng, N. L., Hildebrandt, L., Sorooshian, A., Szmigielski, R., Vermeylen, R., Maenhaut, W., Claeys, M., Flagan, R. C., and Seinfeld, J. H.: Chemical Composition of Secondary Organic Aerosol Formed from the Photooxidation of Isoprene, J. Phys. Chem. A, 110, 9665-9690, doi:10.1021/jp061734m, 2006.

Surratt, J. D., Kroll, J. H., Kleindienst, T. E., Edney, E. O., Claeys, M., Sorooshian, A., Ng, N. L., Offenberg, J. H., Lewandowski, M., Jaoui, M., Flagan, R. C., and Seinfeld, J. H.: Evidence for organosulfates in secondary organic aerosol, Environ. Sci. Technol., 41, 517-527, 2007.

Surratt, J. D., Gómez-González, Y., Chan, A. W. H., Vermeylen, R., Shahgholi, M., Kleindienst, T. E., Edney, E. O., Offenberg, J. H., Lewandowski, M., Jaoui, M., Maenhaut, W., Claeys, M., Flagan, R. C., and Seinfeld, J. H.: Organosulfate formation in biogenic secondary organic aerosol, J. Phys. Chem, A., 112, 8345-8378, 2008.

Surratt, J. D., Chan, A. W. H., Eddingsaas, N. C., Chan, M. N., Loza, C. L., Kwan, A. J., Hersey, S. P., Flagan, R. C., Wennberg, P. O., and Seinfeld, J. H.: Reactive intermediates revealed in secondary organic aerosol formation from isoprene, Proc. Natl. Acad. Sci., 107(15), 6640-6645, 2010.

Szidat, S., Jenk, T. M., Synal, H.-A., Kalberer, M., Wacker, L., Hajdas, I., Kasper-Giebl, A., and Baltensperger, U.: Contributions of fossil fuel, biomass burning, and biogenic emissions to carbonaceous aerosols in Zurich as traced by 14 C, J. Geophys. Res., 111, D07206, doi:10.1029/2005JD006590, 2006. 
Szmigielski, R., Surratt, J. D., Vermeylen, R., Szmigielska, K., Kroll, J. H., Ng, N. L., Murphy, S. M., Sorooshian, A., Seinfeld, J. H., and Claeys, M.: Characterization of 2-methylglyceric acid oligomers in secondary organic aerosol from the photooxidation of isoprene using trimethylsilylation and gas chromatography/ion trap mass spectrometry, J. Mass Spectrom., 42, 101116, 2007a.

Szmigielski, R., Surratt, J. D., Gómez-González, Y., Van der Veken, P., Kourtchev, I., Vermeylen, R., Blockhuys, F., Jaoui, M., Kleindienst, T. E., Lewandowski, M., Offenberg, J. H., Edney, E. O., Seinfeld, J. H., Maenhaut, W., and Claeys, M.: 3-methyl1,2,3-butanetricarboxylic acid: An atmospheric tracer for terpene secondary organic aerosol, Geophys. Res. Lett., 34, L24811, doi:10.1029/2007GL031338, 2007b.

Takahama, S., Gilardoni, S., Russell, L. M., et al.: Classification of multiple types of organic carbon composition in atmospheric particles by scanning transmission X-ray microscopy analysis, Atmos. Environ., 41, 9435-9451, doi:10. 1016/j.atmosenv.2007.08.051, 2007.

Takahama, S., Liu, S., and Russell L. M.: Coatings and clusters of carboxylic acids in carbon-containing atmospheric particles from spectromicroscopy and their implications for cloudnucleating and optical properties. Geophys. Res., 115(D1), D01202, doi:10.1029/2009JD012622, 2010.

Toom-Sauntry, D. and Barrie, L. A.: Chemical composition of snowfall in the high Arctic: 1990-1994, Atmos. Environ., 36, 2683-2693, 2002.
Tsigaridis, K. and Kanakidou, M.: Secondary organic aerosol importance in the future atmosphere, Atmos. Environ., 41, 46824692, doi:10.1016/j.atmosenv.2007.03.045, 2007.

Ulbrich, I. M., Canagaratna, M. R., Zhang, Q., Worsnop, D. R., and Jimenez, J. L.: Interpretation of organic components from Positive Matrix Factorization of aerosol mass spectrometric data, Atmos. Chem. Phys., 9, 2891-2918, doi:10.5194/acp-9-2891-2009, 2009.

Vereecken, L. and Peeters, J.: Theoretical study of the formation of acetone in the $\mathrm{OH}$ initiated atmospheric oxidation of $\alpha \pm$-pinene, J. Phys. Chem. A, 104, 11140-11146, 2000.

Vlasenko, A., Slowik, J. G., Bottenheim, J. W., Brickell, P. C., Chang, R. Y.-W., Macdonald, A. M., Shantz, N. C., Sjostedt, S. J., Wiebe, H. A., Leaitch, W. R., and Abbatt, J. P. D.: Measurements of VOCs by proton transfer reaction mass spectrometry at a rural Ontario site: Sources and correlation to aerosol composition, J. Geophys. Res., 114, D21305, doi:10.1029/2009JD012025, 2009.

Williams, B. J., Goldstein, A. H., Millet, D. B., Holzinger, R., Kreisberg, N. M., Hering, S. V., Allan, J. D., Worsnop, D. R., Jimenez, J. L., and White, A. B.: Chemical speciation of organic aerosol during ICARTT 2004: results from in-situ measurements, J. Geophys. Res., 112, D10S26, doi:10.1029/2006JD007601, 2007. 